\title{
Frederick Catherwood: Engravings and Lithographs from the Mayan Drawings
}

\author{
V I R G I N I A A. M Y E R S
}

When the titles Incidents of Travel in Central America, Chiapas, and Yucatan or Incidents of Travel in Yucatan are mentioned, John L. Stephens, the author, is usually recalled, but the name of Frederick Catherwood, the artist whose illustrations add a significant visual dimension to these volumes, is frequently overlooked. John Lloyd Stephens was a successful New York lawyer and already a popular author before he journeyed to the Yucatan Peninsula. In 1837 he had published an account of his travels in Arabia, and the next year he followed this with his Incidents of Travel in Greece, Turkey, Russia and Poland. Between 1839 and 1842 he and Frederick Catherwood made three expeditions to Yucatan, Chiapas, Quintana Roo and Guatemala. The two books which Stephens wrote based on these experiences quickly became best sellers, although the price of five dollars was then remarkably high for each two-volume set. The two volumes of Incidents of Travel in Central America were published in 1841 by Harper \& Brothers and included 77 engravings, while the two volumes of Incidents of Travel in Yucatan, 1843, by the same publisher, were illustrated with 120 new engravings based on the careful drawings of Frederick Catherwood. These books "describe ... the most extensive journey ever made by a stranger in that peninsula and contain the accounts of visits to forty-four ruined cities, or places in which the remains or vestiges of ancient population were found."1

These were remarkable publications, even though travel books describing exotic lands were popular during the mid-nineteenth century. Capitán del Rio had written an account of his explorations of the ancient Mayan city of Palenque on the edge of the rain forests of

1 John L. Stephens, Incidents of Travel in Yucatan (New York: Harper \& Brothers, 1843), p. iii. 
Chiapas, ${ }^{2}$ and Count Waldeck had engraved an elaborately illustrated portfolio of certain architectural details there, ${ }^{3}$ but nothing either written or illustrated about the Mayan civilization could equal the accounts of John L. Stephens and Frederick Catherwood. J. Eric Thompson in his book The Rise and Fall of Maya Civilization states:

Stephens gave clear and interesting descriptions of the ruins they visited, free of all the twaddle about Atlantis and Egypt common in the 19th century. His accounts of life in Central America a century ago are vivid and delightful. Catherwood's contribution was the excellent illustrations of Maya ruins or sculpture, far superior to any hitherto published. . . Theirs was a fine team, and their two books are as fresh tolay as when they were written and illustrated. 4

Their sojourns in Yucatan and environs went far beyond mere archeological explorations of ancient ruins. The two explorers, while ever searching for significant sites of Mayan civilization, were hardly blinded by a single-minded purpose. They described in detail the character and life of the people they met. In one chapter, for example, Stephens discusses details of housekeeping, bullfighting, a procession and a concert. ${ }^{5}$ Catherwood, although his main concern was making careful studies of the ruins, also included drawings such as a "Seybo Tree," a "Ticul Vase," "A Noria, or well," a "Street in the Village at Nohcacab" and "An Aguada." In general these pictures were printed from wood blocks cut by Dr. Alexander Anderson after the original Catherwood drawings. Their size is usually less than half a page. But the important point here is that Catherwood had the all-inclusive interests of an artist and tried to understand as much as he could about everything he saw. Even when he was limited to the twenty-five plates and a written introduction in his Views of Ancient Monuments, he considered the flora and fauna of the land, the ethnic characteristics of the people, and the history and geography of the region, as well as the ruins and whole city plans. His enlightened speculation and conclusions overall confirm a personality with rich background and broad interests going far beyond the perspectives of an object-oriented archeologist.

2 Antonio del Rio, Description of the Ruins of an Ancient City, Discovered near Palenque, in the Kingdom of Guatemala, in Spanish America (London: H. Berthoud, 1822).

${ }^{3}$ J. F. M. Waldeck, Voyage Pittoresque et Archéologique dans la Province d'Yucatan (Amérique Centrale), pendant les Années 1834 et 1836 (Paris: B. Defour, 1838).

${ }^{4} \mathrm{~J}$. Eric Thompson, The Rise and Fall of Maya Civilization, 2nd ed. (Norman: University of Oklahoma Press, 1966), p. 34.

5 Incidents of Travel in Yucatan, vol. 2, ch. 2. 
Nearly all there is to know about Frederick Catherwood has been gathered in one excellent but thin volume published by Victor von Hagen in $1950 .{ }^{6}$ In the introduction to von Hagen's book, Aldous Huxley wrote about Catherwood's experiences in Yucatan:

From dawn 'til dusk, day after day and for weeks at a stretch this martyr to archaeology had exposed himself to all the winged and crawling malice of tropical nature. Ticks, ants, wasps, flies, mosquitoes: they had all bitten him, stung him, drunk his blood, infected him with malaria. But the man had grimly gone on drawing. Itching, swollen, burning or shuddering with fever, he had filled whole portfolios with the measured plans and elevations of temples, with studies of Mayan sculpture so scientifically accurate that modern experts on pre-Columbian history can spell out a date of a stele from Catherwood's representation of its, to him, incomprehensible hieroglyphics.7

And J. L. Stephens recorded that even while he was ill Catherwood persisted in making his drawings: "An Indian held an umbrella over Mr. Catherwood's head to protect him from the sun, and while making the drawing, several times he was obliged by weakness to lie down and rest. I was disheartened by the spectacle. . . . It was so disagreeable to be moving along with this constant liability to fever and ague, that I felt very much disposed to break up the expedition and go home, but Mr. Catherwood persisted."8 Perhaps the very fact that Catherwood continued to draw the Mayan ruins, even returning with Stephens following terrible illness and delerium, is enough evidence that his drawings were literally labors of love. But, of course, the drawings themselves are another proof that Catherwood regarded the ruins and the Mayan people warmly.

Stephens in one passage describes Catherwood at his easel:

... the platform had no structure of any kind upon it, and was overgrown with trees, under the shade of which Mr. Catherwood set up his camera to make his drawing; and looking down upon him from the door of the Castillo, nothing could be finer than his position, the picturesque effect being greatly heightened by his manner of keeping one hand in his pocket, to save it from the attacks of the mochetoes, and by his expedient of tying his pantaloons around his legs to keep ants and other insects from running up. ${ }^{9}$

That narrative, I suspect, was meant to amuse the reader, but having myself attempted to sit still long enough to draw with all of that

6 Victor Wolfgang von Hagen, Frederick Catherwood Archt. (New York: Oxford University Press, 1950). This has been supplemented by von Hagen's more recent book, F. Catherwood, Architect-Explorer of Two Worlds (Barre, Massachusetts: Barre Publishers, 1968).

7 Von Hagen, Frederick Catherwood Archt, p. xv.

8 Stephens, Incidents of Travel in Yucatan, vol. 2, p. 125.

9 Ibid., p. 268. 
"crawling malice" and steaming humidity, I can only exclaim, "Poor Catherwood!" and wonder if Stephens could have written those words if he had had to sit and concentrate alone on his own drawings for days and weeks and months at a time in Yucatan.

Victor von Hagen's research informs us that Catherwood's art training began at the Royal Academy in London, where Sir John Soane lectured on architecture. Not only did he teach about domes, blocking courses, arches, pediments and pedestals, but Soane insisted that "the student must also draw the human figure with correctness and have a competent knowledge of painting and sculpture. . . ."10 Soane introduced Catherwood to the engravings of Giambattista Piranesi, and Catherwood was so moved by the Italian's volume Della magnificenza ed architettura de Romana that he eventually went to Rome to view the ruins for himself. Before he returned to London three years later, he had made journeys to Greece, Sicily and Egypt, making careful drawings at ancient sites of civilization. For Catherwood, after the excitement he had experienced in those Mediterranean countries, London had little appeal, and he was happy for the opportunity to return to Egypt at the invitation of Robert Hay. Hay and his retinue of skilled topographical draughtsmen, antiquarians, architects and artists laid down a systematic basis of Egyptian archeology between 1828 and 1838. Catherwood's special contribution to these expeditions included his detailed scale plan of Thebes. This drawing eventually was enlarged into an enormous scenic panorama which was shown in London and New York.

After having worked intensively for a year at such historical sites as Hierakonpolis, Edfu and the Isle of Philae along the Nile, Catherwood left Cairo by camel caravan for the Middle East. By this time, according to Victor von Hagen, "Catherwood dressed as an Arab with robe and turban ... was well versed in Oriental manners and could speak fluent Arabic, Italian and Hebrew." 11

In Jerusalem, at the Mosque of Omar, Catherwood spent six weeks investigating "every part of the mosque and its precincts," as he reported in his own words. It was a truly bold and remarkable excursion into the heart of the Arab world, and had it not been for a series of lucky circumstances Catherwood might have lost his life while making his drawings inside the Mosque. Catherwood wrote:

... But when I heard of the near approach of the Ibrahim Pasha, I thought

10 Reginald Blomfield, Architectural Drawing and Draughtsmen (London: Cassell, 1912), p. 64.

11 Von Hagen, Frederick Catherwood Archt, p. 30. 
it was time to take leave of Jerusalem. The day after my departure, he entered, and as it happened, several English travellers of distinction arrived at the same time. Anxious to see the mosque, they asked permission of Ibrahim, whose answer was characteristic of the man, to the purport, that they were welcome to go if they liked, but he would not insure their safe return, and that he could not venture to outrage the feelings of the Musselmen, by sending an escort with them. Here he was met with the story of my recent visit. He said it was impossible; the dervishes were summoned; the governor was summoned, and an eclaircissement took place, which must have been a scene of no small amusement.

It was more than simple curiosity that urged this rash attempt, and its fortunate issue enabled me, with my associates, to make a complete and scientific survey of the mosques, vaults, gateways, and other objects comprised within the extent of the area. . .12

But now all Catherwood's drawings of the Mosque of Omar have been lost.

The era of the painted panorama was at its height in London when Catherwood returned. In need of money, Catherwood found a job with Robert Burford and his famous panoramas in Leicester Square. One day in 1836, John Lloyd Stephens met Catherwood at Burford's Panorama as the artist lectured before his own mural of Jerusalem. Soon afterwards Catherwood was in New York City, working first as an architect and then introducing America to his own "Splendid Panorama of Jerusalem." Von Hagen states:

... Advertisements inserted in all of the leading New York papers announced Jerusalem, "a painting of the largest class, 10,000 square feet from drawings of Mr. Catherwood brilliantly illuminated every evening by upward of 200 gas-lights-admission 256." It had an excellent press; the Mirror's critic was fully impressed by the artist's background.

"The establishment of Mr. Catherwood (a gentleman well known through the country for those admirable lectures on the 'land of the East' the result of many years of observant travelling) is on a scale equal to the successive production of a whole series of magnificent panoramic paintings, from original drawings - the most attractive of the whole host of London exhibitions."13

The time was ripe indeed for the widespread acceptance of the panorama in America. Robert Barker had patented the panorama in Edinburgh in 1787. Afterward his son, Henry Ashton Barker, promoted the popularity of the panorama and was followed by a succession of American artists. Robert Fulton, the first of these, purchased the importation rights to the panorama in France. ${ }^{14}$ Eventually James Thayer

12 Frederick Catherwood, Letter to W. H. Bartlett, as quoted by Von Hagen, Frederick Catherwood Archt, p. 36.

13 Von Hagen, Frederick Catherwood Archt, p. 48.

14 This is the same Robert Fulton (1765-1815) who successfully employed the steam engine to propel boats. 
acquired these rights and was followed by Colonel John Trumbull (1756-1843), John Vanderlyn (1775-1832), and Thomas Cole (18011848 ) and his serial narratives of $1836 .{ }^{15}$ Barbara Novak points out:

Cole's serial narrative involved another important factor. The entire philosophy of "Course of Empire" could be grasped only if one proceeded in systematic fashion from the Primitive to the Pastoral State, then on to Consummation of Empire, Destruction and Desolation. "Voyage of Life" obviously could only reach its foregone conclusion by traversing the sea of life with Cole's Everyman from infancy to old age-rehearsing the past for the old and providing a prospective moral textbook for the young. Thus the public was already experiencing a kind of "motion art" with Cole's cycles, albeit the spectators were the ones in motion.16

So, too, with Catherwood's famous panorama. By 1849 Henry Lewis had produced a "Mammoth Panorama of the Mississippi River," 45,000 square feet of painted canvas, which was slowly unrolled before a seated audience as lecturers and piano music amplified the visual commentary. ${ }^{17}$ Of course it was a moving picture.

It was less than a year following the return of Stephens and Catherwood from the Yucatan Peninsula that Incidents of Travel in Yucatan was published in New York City. Less than two years before, the two volumes of Incidents of Travel in Central America, Chiapas, and Yucatan had been published. It had been enough work for Stephens to complete his manuscripts for the books in time for them to be set in type; but for Catherwood, final preparation of the drawings from which the original engravings were made to illustrate the books was an incredible task. Incidents of Travel in Central America included the work of at least eight different engravers, while Incidents of Travel in Yucatan required the services of fourteen craftsmen, with five of the men used to make plates for both books. The so-called "engravings" are, with few exceptions, not really engravings in the purest sense of the word, but rather etchings with engraved skies and sometimes additional touches with the burin to heighten certain images.

One can guess that Catherwood was not entirely satisfied with the quality of the prints made after his drawings; he was, after all, a firstrate creative artist, while those who etched and engraved the copper plates were professional craftsmen who used their techniques to reproduce rather than to create. Even so, there is considerable incon-

15 Lee Parry, "Landscape Theater in America," Art in America (NovemberDecember, 1971), passim.

16 Barbara Novak, "Grand Opera and the Small Still Voice," Art in America (March-April, 1971), p. 66.

17 Ibid., p. 69. 
sistency in the way the plates were printed. Print quality ranges from poor to superb, with the largest number falling in the range of fair to good. Examples of superbly printed impressions in the volumes owned by The University of Iowa Libraries include A.L. Dick's "East Side of Court Yard of Palace at Palenque" (Incidents of Travel in C'entral America, Vol. II, p. 314) and M. Osborne's "Kabah, 3rd Casa" (Incidents of Travel in Yucatan, Vol. I, p. 398).

Inks vary from a rather transparent black, giving the feeling that the pigment used was dark gray as seen in A. L. Dick's "Tablet on the Back Wall of Altar, Casa No. 3, Palenque" (Frontispiece, Incidents of Travel in Central America, Vol. II), to an extremely intense warm black ink used by Graham to print "Back View of the Castillo of Tuloom" (Incidents of Travel in Yucatan, Vol. II, p. 392).

With few exceptions the engraving and etching is quite monotonous, the inevitable result when methods and formulae limit the creative possibilities of the burin and the etched line. S. H. Gimber's prints are readily identified by a right-angle crosshatch resembling screenwire which, although remaining essentially unchanged regardless of the subject matter, is used to express shadows on rocks or stone sculpture, as in "Idol at Copan" (Incidents of Travel in Central Amer$i c a$, Vol. I, p. 156, no. 3), the inside lip of a cavern entrance, "Bolonchen" (Incidents of Travel in Yucatan, Vol. II, p. 148) or sky, as in "Macoba" (Ibid. p. 218). J. N. Gimbrede uses the same type of crosshatch to express water reflection of a rock in "San Miguel" (Ibid. p. 363).

Foliage is rendered with etched scallops, as seen in J. N. Gimbrede's "Gobernador-Uxmal" (Frontispiece, Incidents of Travel in Yucatan, Vol. I) and by wavy parallel lines for palms and yucca observed in M. Osborne's "Yalahao" (Incidents of Travel in Central America, Vol. II, p. 347). Undoubtedly among the platemakers there was a paucity of first-hand experience with the sort of jungle growth peculiar to Yucatan, to say nothing of the Mayan sculptures and constructions. Even Catherwood had difficulty when he commenced drawing Mayan stelae at Copan, and Stephens reports in the early pages of the first volume of Incidents of Travel in Central America:

As we feared, the designs were so intricate and complicated, the subjects so entirely new and unintelligible, that he had great difficulty in drawing. He had made several attempts, both with the camera lucida[18] and without but failed to satisfy himself or even me, who was less severe in criticism.19

$18 \mathrm{~A}$ device using mirrors or a prism which will allow an external image to be projected upon a flat surface so that it may be traced.

19 Stephens, Incidents of Travel in Central America, p. 120. 
Other techniques commonly used by the platemakers included a boring use of wiggly lines, as seen in Graham's print of Tuloom already mentioned (Incidents of Travel in Yucatan, Vol. II, p. 392), and occasionally a delicate dotted technique to express features on sculpture, as in "Stucco Bas Relief, Palenque," by Rawdon, Wright, Hatch and Smilie (Incidents of Travel in Central America, p. 311). But the most common technique, employed by all the platemakers, was the use of carefully-engraved parallel lines to make sky and clouds. These parallel-line skies, along with the consistent image size, are unifying factors for the books. The four volumes show some interesting skies. One of the most subtle and beautiful is A. Halbert's "Sabachtsche" (Incidents of Travel in Yucatan, Vol. II, p. 42), which is so delicately engraved that it creates the feeling of a wash drawing.

Yucatan is well known for dramatic sky effects. A typical day during the rainy season from June through October dawns with a clear transparent turquoise blue heaven. During the day white clouds begin to form, until sometime late in the afternoon huge thunderheads rumble and flash with the coming storm. Yucatan is so low and flat that a broad skyscape may be seen in one sweeping glance, and it is sometimes possible to see the scrubby jungle made almost white by blinding sun against a background of inky purple reaching all the way to the ground and then upward where it is interrupted by cracklings of forked lightning. A little to the right or left there may be a greenish-yellow band close to the earth where rain is falling in a cloudburst, and yet in another portion a brilliant rainbow will trace its spectrum near a fragment of celestial blue, the whole composition being bound together by a thin band of flat earth punctuated with sisal spines and the vast concave sky. Surely Catherwood was impressed by these daily violent episodes of nature, and he recorded them in his drawings. For example, see the sky in "Gymnasium, Chichén Itzá" (Incidents of Travel in Yucatan, Vol. II, p. 303), executed by J. N. Gimbrede, or "Xampon" (Ibid., p. 124), engraved by Johnson, or "Macoba" (Ibid. Vol. II, p. 218).

In spite of the monotony of technique employed in the prints, these are not without merit. The work of some of the best professional engravers and etchers of the time is included in the books. Even Prud'homme, one of the finest Parisian engravers, is represented with two prints in the first volume of Incidents of Travel in Yucatan: "West Building, Monjas, Uxmal" (p. 303) and "S. E. Angle of Monjas, Uxmal" (p. 307). Others included members of the prestigious National Academy: Alfred Jones, David Johnson, John A. Rolph and G. Hal- 
bert. The plates are generally crisp and definitive, a characteristic of good intaglio prints.

If Catherwood had been able to make the plates himself, these would probably have gone far beyond the bounds of the reproductions they are and perhaps would have ranked closer to Piranesi's "Views of Ancient Rome." But time was short, for there were 77 prints which had to be made for the two volumes of Incidents of Travel in Central America, and not long afterwards 120 new plates were required for Incidents of Travel in Yucatan, and these had to be prepared in six months' time. The drawings consequently had to be farmed out to about fifteen different professional platemakers and printers. It was not even possible, evidently, to give all of the drawings of one ancient city to a single craftsman. In Incidents of Travel in Yucatan, six different men made plates to illustrate the chapters on Chichén-Itzá, while five worked on the drawings of Uxmal. To Catherwood it was a compromise he could not avoid and, as it turned out, but another example of the misfortune which followed the artist during his lifetime.

Soon after his return with Stephens from their last expedition to Yucatan, Catherwood filled his Panorama Rotunda with a special exhibition of treasures from Central America. On display were Mayan artifacts, stone sculptures, ceramics, carved wooden lintels and hundreds of Catherwood's original drawings and his oversized watercolors of the ancient sites they had visited and of the people they had met. One evening, shortly after closing hours, there was a fire at the Rotunda and it quickly burned to the ground, all the contents being destroyed. Even today that loss remains incalculable. The New York Herald reported on August 1, 1842:

This fire is likely to prove much more disastrous than we at first anticipated. For we find that when Messrs. Catherwood and Stevens [Stephens] returned to this city from their last trip to Central America they deposited all their valuable collections and curiosities, pieces of the ruins, specimens, drawings, plans and everything that they had collected in their painful and perilous tour. These things are a great loss; no money can replace them. . . .20

For Catherwood personally the loss must have had terrifying dimensions. To see the bulk of his most important work as an artist-archeologist utterly devastated would almost surely have driven a weaker man to the point of suicide. Catherwood, instead, drove himself to see that the plates for the new Incidents of Travel in Yucatan were prepared by the best engravers available. It is a characteristic among

20 New York Herald (August 1, 1842), p. 2. 


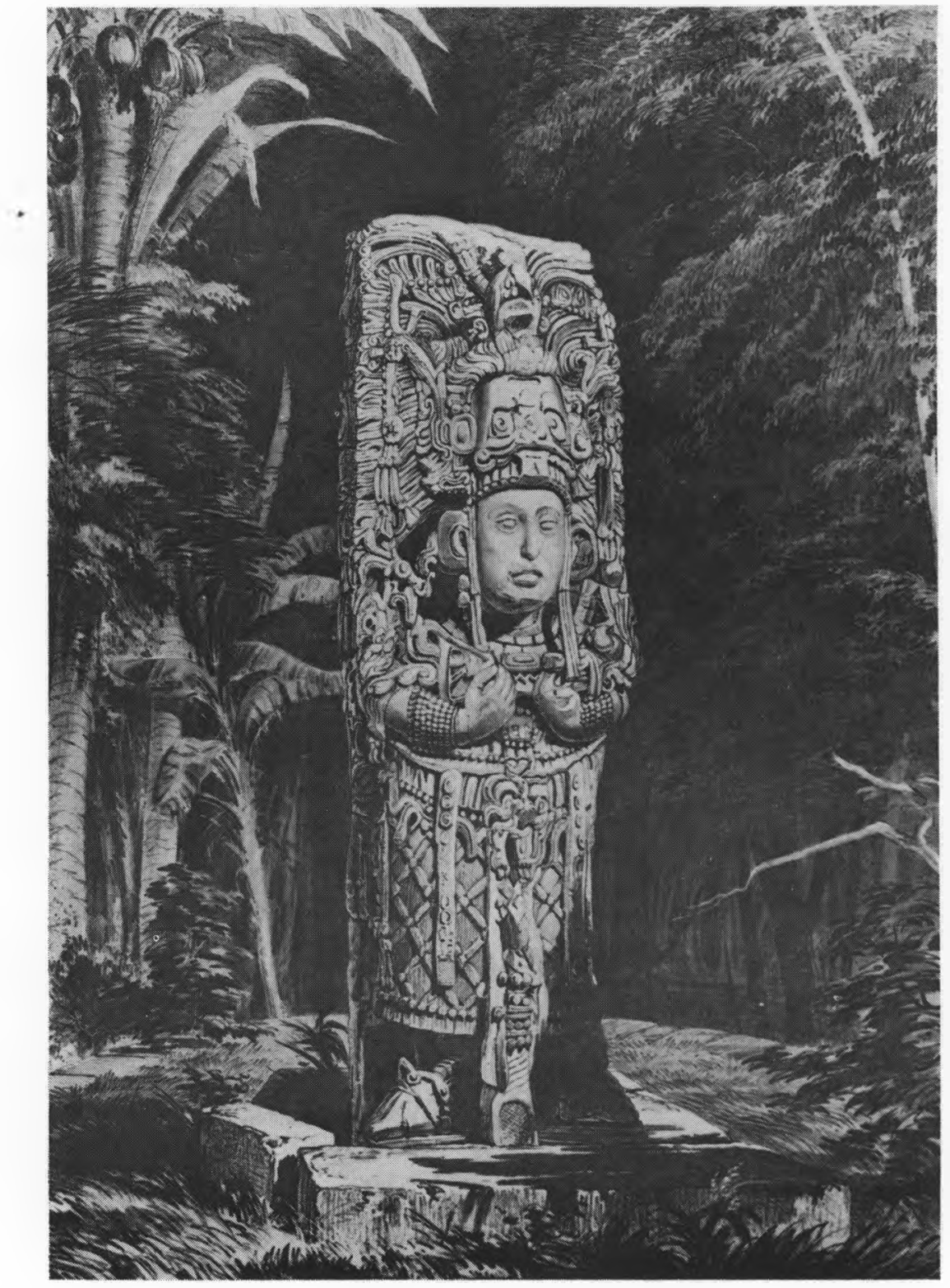

A stone idol at the ruined Mava city of Copán. Standing eleven feet eight inches tall. it was carved from a single block of limestone around the year 782 A.D. On its back and sides are glyphs recording astronomical data. From Frederick Catherwood's Views of Ancient Monuments in Central America, Chiapas, and Yucatan ( 1.848 ). 


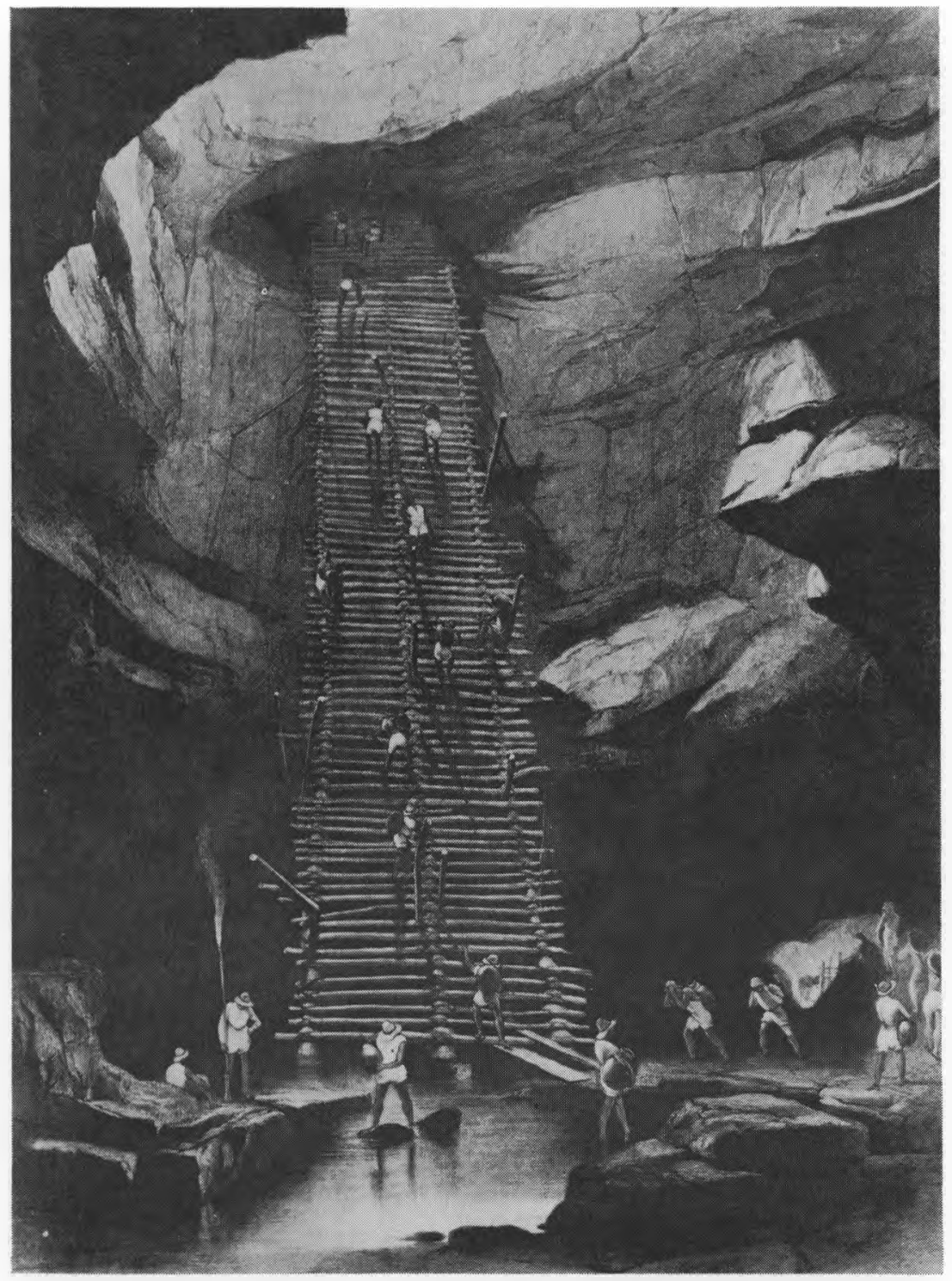

Catherwood's view of an underground well near the village of Bolonchen in Yucatan. The central ladder, constructed of tree trunks lashed with withes, was eighty feet long. 
first-rate artists to turn toward their work rather than away from it in time of crisis.

At this juncture Stephens and Catherwood decided to publish an illustrated folio on American antiquities so comprehensive in its scope and so lavish in its production that only Audubon's Birds of America would have been comparable. Surely the worlds of art and archeology are poorer because Catherwood and Stephens were never able to find enough subscribers to support that ambitious enterprise. So Catherwood made instead a more modest book illustrating a few of the ancient monuments he had sketched. It was his first and only book, limited to 300 sets and titled Views of Ancient Monuments in Central America (1848). It contained twenty-five excellent lithographs colored by hand and a fine engraved map of the Peninsula in red and black. Touchingly, Catherwood dedicated his book to his friend John L. Stephens:

To John L. Stephens, Esq., These views of ancient monuments in Central America, Chiapas, and Yucatan are inscribed by his very sincere friend, Frederick Catherwood.

Catherwood himself wrote the "Introduction" for Views of Ancient Monuments, in which he described some of the historical and geographical details of the lands visited. He must be complimented for his deductions about the Mayans. With regard to the various theories that have been formed to trace the nations that people the American continent, he wrote:

... through their migrations, to their original habitation in the Old World, we find them all resting for support upon a few vague similarities of rites and customs, more or less common amongst every branch of the human family. Besides, the idea that civilization, and its attendant arts, is in every case derivative, and always owing to a transmission from a cultivated to an unpolished people, is eminently unphilosophical, as it only removes further back, without explaining the original difficulty of invention, which must somewhere have taken place; and if at anytime in one country, undoubtedly a similar train of circumstances may have led to similar results in another. ... The results arrived at by Mr. Stephens and myself, after a full and precise comparative survey of the ancient remains, coincide with this opinion and are briefly:-that they are the production of an indigenous school of art, adapted to the natural circumstances of the country, and to the civil and religious polity then prevailing,--and that they present but very slight and accidental analogies with the works of any people in the Old World. . .21

These thoughts were not the ones being advanced commonly, in which the Mayan Indians were thought to be some lost tribe from an

21 Frederick Catherwood, Views of Ancient Monuments in Central America, Chiapas and Yucatan (Barre, Mass.: Barre Publishers, 1965), pp. 8-9. 
early fragment of Western civilization, the Carthaginians or the lost souls of Atlantis, for example. The conclusions of Catherwood and Stephens have been confirmed by the research of archeologists during the last one hundred years. On page three of his introduction to Monuments, Catherwood noted that "whether these mounds or pyramids are in general solid, or contain, in all cases, passages and apartments is not ascertained. In the few that have been opened by accident or design, small arched rooms have been found." Catherwood's speculation has been positively realized in the wonderful discoveries made by archeologists in our own time. To name two of the most exciting finds in the pyramids Catherwood drew, there is the interior staircase inside the "Teocallis of Chichén-Itzá," Plate XII, discovered several decades ago. That staircase had once been an exterior facing on a smaller pyramid leading to a modest temple on top which contained a fine sculpture of Chac-mool and another of a red jaguar with splendid turquoise spots and eyes. And in "General View of Palenque," Plate VI, Catherwood has placed the huge pyramid with the laternamed Temple of the Inscriptions on top, in the central position of his composition. During three years from 1949 to 1953, Alberto Ruz excavated a deep staircase zig-zagging for 80 feet as it descended from the temple on the top to a fabulous tomb which yielded a richly carved stone sepulchre, gold jewelry, ceramics, memorable stucco sculptures and a jade mask covering the skull of the entombed nobleman.

Artistically, Views of Ancient Monuments has considerably more merit than the Stephens' books on travel in Central America and Yucatan. The folio pages measure $161 / 2$ by $207 / 16$ inches and the pictures vary in dimensions from 10 or 11 inches by 15 or 16 inches. They were lithographed and colored by six of the best English lithographers of Catherwood's own choosing.

The ten plates by Andrew Picken are the artistic high point of the folio. The clarity and crispness of Picken's executions are emphasized with intense dark values expressive of ruined building interiors and jungle foliage (for example, see Plate XVI, "Interior View at Kabah," and Plate I, "Idol at Copan," respectively); and, further, the prints are illuminated by a sparkling transparent light in such examples as Plate XII, "Teocallis at Chichén-Itzá," and Plate VI, "General View at Palenque."

The aesthetic quality of the seven lithos of Henry Warren is, as a whole, not so consistent as those of Picken. Somehow the colors seem thinner and therefore less rich by comparison. But Warren did contribute some outstanding plates to the folio, especially Plate XXV, 
"Colossal Head at Izamal," an artifact which is now destroyed.

Of John C. Bourne's two lithographs, the "Gateway at Labna" (Plate XIX) is the finest. William Parrot contributed four prints, among them the beautiful "Temple at Tuloom" (Plate XXIV), which includes the only known portrait of Catherwood: he pictures himself stretching a measuring tape with John L. Stephens. In the jungle at the far left is a man tramping off into the verdure with a gun. This is Catherwood's commemoration of that peculiar incident when Dr. Cabot, in search of an ocellated turkey, accidentally stumbled onto another group of buildings, some with important frescoes which the explorers had not yet seen and which they would otherwise have missed because of the dense jungle undergrowth.

Thomas Shotter Boys, reported to have been the most famous among the lithographers, executed "Gateway of the Great Teocallis, Uxmal" (Plate XI). The sixth lithographer contributing one plate to the folio was George Belton Moore, whose print, "Las Monjas, Chichén-Itzá" (Plate XXI), seems cold and gray and rigid when compared to those of Picken and Warren.

Having explored many of the same sites illustrated in the lithographs, I have observed that the grandeur depicted by Catherwood was essentially that of the Mayas and that he was a splendid reporter of the realities and was able to imbue them with some of the love and wonder he himself felt for the ruins. The lithographs are not saccharine or romantic overstatements, although the prints certainly are an authentic manifestation of some of the best and most lasting elements of nineteenth-century landscape art prior to the Civil War. While many of the American painters such as Thomas Cole and Frederick Church were often painting rather theatrical compositions, Catherwood's lithographs are generally without obvious dramatics; there is a kind of serenity which pervades his scenes and evokes a sense of the mystery and solitude which may be experienced to this present day by any sensitive visitor to the Mayan jungles.

In eighteen out of twenty-five prints, Catherwood included figures of the Indians. Their presence goes beyond a mere indication of the scale of the ancient buildings. These are members of the human race at work or play, participating in a real and possible life in a tropical region of the earth. In Plate XV, "Portion of La Casa at Las Monjas, Uxmal," a native boy is holding the paw of his dog, one of those tough little short-haired mongrels which, even today, are seen wherever there are people in Yucatan.

In Plate VIII, "General View of Las Monjas, Uxmal," native workers 
are clearing away the vines and bushes. On these journeys it was always the job of Stephens to find the monuments and then to have them cleared of the verdure so that Catherwood could proceed with his drawings. In Plate XVI, "General View of Kabah," some native porters wearing sandals are carrying one of the carved wooden lintels found in that ancient city. It could well be one of the lintels lost in the fire at Catherwood's panorama. Plate XVIII, "Well and Building at Sabachtsche," is a composition with figures, mostly women and children, drawing and carrying water. Catherwood evidently regarded these people as handsome and intelligent, for he gave them a very respectable dignity.

Plate XX, "Well at Bolonchen," is Catherwood's reconstruction of the well as he believed it would have appeared while in daily use. Stephens wrote: "Every year, before having recourse to it, there was a work of several days to be done in repairing the ladders." But when the two explorers arrived, the ladders were in bad condition. Nevertheless, they undertook to visit the well in spite of the dangers:

... following the Indians, each with a torch in hand, [we] entered a wild cavern, which, as we advanced, became darker. At the distance of 60 paces the descent was precipitous, and we went down by a ladder about twenty feet. Here all light from the mouth of the cavern was lost, but we soon reached the brink of a great perpendicular descent, to the very bottom of which a strong body of light was thrown from a hole in the surface, a perpendicular depth, as we afterward learned by measurement, of two hundred and ten feet....

From the brink on which we stood an enormous ladder, of the rudest possible construction, led to the bottom of the hole. It was between seventy and eighty feet long, and about twelve feet lengthwise, and supported all the way down by horizontal trunks braced against the face of the precipitous rock. The ladder was double, having two sets of flights or rounds, divided by a middle partition, and the whole fabric was lashed together by withes. It was very steep, seemed precarious and insecure, and confirmed the worst accounts we had heard of the descent into this remarkable well.

Our Indians began the descent, but the foremost had scarcely got his head below the surface before one of the rounds slipped, and he only saved himself by clinging to another. The ladder having been made when the withes were green, these were now dry, cracked, and some of them broken. We attempted a descent with some little misgivings, but by keeping each hand and foot on a different round, with an occasional crash and slide, we all reached the foot of the ladder; that is, our own party, our Indians and some three or four of our escort, the rest having disappeared.22

Catherwood noted in his description of Plate XX: "The cenote cavern is now no longer used; the ladder has been destroyed."

22 Stephens, Incidents of Travel in Yucatan, vol. 2, pp. 146-148. 
In total effect, the plates are well composed and are rich with details which any curious and sensitive viewer would enjoy while being apprised of some of the important realities of the Mayan scene.

An excellent facsimile in folio form of Catherwood's Views of Ancient Monuments is owned by The University of Iowa Libraries. ${ }^{23}$ In the original work, each of the twenty-five plates, with the exception of the map, had been hand painted in transparent watercolors, a common practice in nineteen-century printmaking. The original plates distinguish themselves from the facsimiles by the delicacy, freshness and subtlety of colors one associates with originals. By comparison, the facsimiles are somewhat more two dimensional and lacking in the depth and mystery of the originals. Typically, colors printed by massproduction techniques are restricted to a standardized range, while an original can have countless variations. Thus some of the prints which come off rather weakly as facsimiles are infintely more exciting as originals. Compare especially Plate IV, "Broken Idol at Copan," where the facsimile makes it one of the less enchanting prints, while in the original a reddish-brown deer seems to hurdle forth in a three-dimensional leap beyond the surface plane of the print itself, the whole scene being unified by a mystical blue haze and a patch of transparent cobalt sky seen through a break in the jungle foliage.

The originals show some bright notes of color not seen in the facsimiles, but for my taste these are sometimes a little on the acid or sharp side and tend to divorce themselves from the remainder of the composition. One of these colors is a bright carmine red in the clothes of some of the natives pictured, serving to emphasize the intensity of the jungle verdure and employing an old artist's trick of painting a large area in one color or variations of it and then using a small amount of its complement to set up a kind of tension or dynamic relationship between the two.

Catherwood did take some liberties in making his drawings, but it appears that his purpose was to clarify or to amplify the visual information he imparted through his pictures. In Plate XIII, "General View of Uxmal," which shows the so-called "Dove Cots," the entire length of the east side of the quadrangle is depicted without obstructing underbrush. Even today underbrush and trees conceal sections of that wall from the site where Catherwood made his drawing. In Plate XXII, "Teocallis at Chichén-Itzá," Catherwood has taken the liberty of

23 An example of the original edition was examined in the Print Study Room at the Chicago Art Institute as a basis for making comparisons with the facsimile edition at Iowa. 
placing in the foreground one of the great serpent heads from the base of the Castillo, while the pyramid rises in the background, its base, where the serpent heads are actually found, being covered with verdure.

In Plate II, "Pyramidal Building and Fragments of Sculpture at Copan," the facsimile has produced a thin flat picture, with the pyramid in the rain forests more than half covered by the trees and vines. The original tells a much more interesting story, as that same pyramid emerges in such a way as to imply an enormous treasure box of marvels lying untouched and craving discovery under its tangled covering. That is a more truthful statement, I believe, for even today hundreds of such pyramids tantalize the imagination of the explorer as he views a swathe of arrow-leafed philodendron, hairy-stemmed begonias, graceful maiden hair ferns, exotic sunbursts of earth-red lichens and brilliant green blankets of various mosses clinging to handcarved limestone rocks, buff colored or bluish gray according to the light, and with palms and ramon to increase the height of a Mayan "hanging garden of Babylon."

Nothing so pictorially beautiful and comprehensive has ever been made of the Mayan civilization; it will always remain regrettable that Catherwood was not financially able to make the original oversizedportfolio of American antiquities he planned with Stephens. It would have contained 100 or 120 prints and included an article by William H. Prescott, who had just completed his monumental Conquest of Mexico (1843). Other contributors would have been Jefferson's Secretary of the Treasury, Albert Gallatin, who was an excellent ethnologist, and Sir John Wilkinson, "the best authority on all points of resemblance between American signs and symbols and those of Egypt."24

After Views of Ancient Monuments had been published, Catherwood went to South America, where he worked for a railway company making the surveys for the first railroad in South America. Von Hagen's biography reports the details of this difficult time for Catherwood. ${ }^{25}$

On October 12, 1852, Catherwood was aboard the Arctic on a return trip from England to America. In heavy fog there was a head-on collision with a French ship. The crew of the Arctic quickly occupied all the available boats, leaving the passengers to inevitable drowning. Von Hagen writes:

24 Letter from Catherwood to William Prescott, 25 March 1843, requesting his support of the project, quoted by Von Hagen, Frederick Catherwood, Archt, p. 68.

25 Von Hagen, Frederick Catherwood, Archt, ch. 10. 
Two weeks later the New York papers spilled the news in their largest type. . . . Then followed day upon day, name after name of the missing passengers. For two weeks the dailies swept everything from their first page to bring the details of the tragedy that had taken 300 lives. . . . One by one, the survivors told of the last acts of those who had perished, and later the newspapers printed long obituaries of each of the victims. All, that is, except Frederick Catherwood. Not a word of the friend of Keats, Severn, Shelley; and, in America, of Prescott, Bancroft, and Stephens; not a word of the companion of Bonomi, Robert Hay, and Wilkinson; the pioneer of Egyptology, the architect-draftsman of the Mosque of Omar, the panoramist of Leicester Square, the New York architect, the co-discoverer of the Mayan culture, the builder of South America's first railroad, the Argonaut of California. The New York newspapers, which over a period of fifteen years had printed many news releases on one of the greatest archaeological-explorers that ever lived did not once mention his name. That is until many days had passed and inquiries from remembering friends came to the editor of the New York Herald. Then, as a sort of afterthought, Catherwood appeared in a single line under "The Saved and the Lost":

"Mr. Catherwood also is missing."26

Frederick Catherwood was but fifty-three when he died. Today he and his fascinating works as an artist-archeologist are known only to a few.

26 Ibid., pp. 116-117. 